\title{
Survey of Medicinal Plants of Ganganagar District
}

\author{
Sandeep Kumar Yadav \\ Lecturer, Department of Botany, Govt. Dungar College, Bikaner (Raj), India
}

\begin{abstract}
This work has the objective a survey of the species of plants and their uses as medicinal, which are utilized for ethano-medicinal values in the region of Ganganagar district. The area of study is recognized by a vast diversity of species of plants and habitats of great Indian Thar desert, about 59 species, belonging to 16 vascular plant families and one pteridophyte family.
\end{abstract}

Keywords: Medicinal plants, Thar desert, Ethnobotany, Ganganagar district.

\section{INTRODUCTION}

Rajasthan, literally, "Land of Kings" is India's largest state by area. It is located on the north-western side of the country, where it comprises most of the wide and inhospitable Thar Desert. Sri Ganganagar is a planned city and the northern-most city in the Indian state of Rajasthan, The climate of Sri Ganganagar varies to extreme limits. Summer temperature reaches $50^{\circ}$ Celsius and winter temperature dips just around $0^{\circ}$ Celsius. Irrigation via the Gang canal and Indira Gandhi Nehar Priyojna has changed the flora and fauna of Ganganagar. This paper emphasizes the description of some plant species belonging to different families with their medicinal importance which is found among the flora of Ganganagar region 1, 2. Local people of the study area play a vital role in using the medicinal plants in ethnomedicine3. These people are using different plant parts as folk remedies and use daily as food, fodder, and shelter. The traditional information about using medicinal plants of the study area is degraded day by day. So there is an urgent need to documentation the traditional knowledge about the medicinal flora of study area for the benefit of next generation

\section{MATERIALS AND METHODS}

Several field trips were conducted in all parts of the Ganganagar district to collect and documentation of such knowledge. Interviews were conducted with experienced persons different society as they have traditional information regarding medicinal importance of plants.

\section{OBSERVATION AND DISCUSSION}

Six important ethno medicinal plants are described here with their local name, family and their medicinal uses which are formed in the study area.

1. Withania somnifera, known commonly as ashwagandha4, Indian ginseng, poison gooseberry, or Winter Cherry, is a plant belonging to the Solanaceae or nightshade family. Several other species in the genus Withania are morphologically similar. It is used as an herb in Ayurvedic medicine. It is cultivated in many of the drier regions of India.

Medicinal values- The plant's long, brown, tuberous roots are used for medicinal purposes in Ayurveda, the berries and leaves are applied externally to tumors.

2. Leptadenia pyrotechnica is the botanical name of a desert herb of the family Asclepiadaceae. It is known as khimp in Hindi5. It has played an important role in the desert afforestation programs. The herb Khimp is a strong soil-binder an as such is one of the pioneer species in sand dune fixation.

Medicinal values- The plant is used in thatching huts. The pods of this shrub, known as khimpoli in Hindi, ripe in the month of March which is of medicinal value and used as vegetables. The plant fiber is used for making ropes. The plant is browsed by all stock, but especially by camels for which it is considered a good fodder.

3. Aloe vera is a succulent plant species. The species is frequently cited as being used in herbal medicine since the beginning of the first century AD. Extracts from A. vera are widely used in the cosmetics and alternative medicine industries.

Medicinal values- Aloe vera is a skin healer. It has long been in use for wounds, burns and skin problems.

4. Calotropis procera is a species of flowering plant in the family Apocynaceae, is native to North Africa Medicinal values- The plant is known as aak in Hindi. The latex is said to have mercury-like effects on the human body and is sometimes referred to as vegetable mercury. Sometimes leaves are fried in oil for medicinal purposes. 
5 Capparis deciduas grow wild and unattended throughout India's arid northwest regions6. In Rajasthan and Gujarat, the little berry is a staple within the rural economies. A prime reason for the fruit's significance is the tree's ability to survive in regions where no other vegetation can: Indeed, its only growing requirements are low rainfall, shallow soils, and dry, hot temperatures.

Medicinal value- Capparis has been used in traditional medicine for centuries. Indian tribes have utilized fruits, roots, and bark to concoct various remedies. In Ayurveda, capers are hepatic stimulants and have been used for arteriosclerosis, as a diuretic, and as a kidney disinfectant.

6. Ziziphus numularia- It also called Jharber, is a species of Ziziphus native to the Thar Desert of western India and southeastern Pakistan and South Iran

Medicinal value-

A. Leaves: - The leaves are used to treat scabies and other skin diseases, it has antipyretic nature and reduce obesity. The fruit is cooling, tonic, digestible, laxative aphrodisiac and removes biliousness, thirst, vomiting and burning sensations.

B. Fruits -The fruits are a good source of vitamin $\mathrm{C}$ and sugars and contain appreciable amounts of mineral constituents. The dried fruits contain alkaloids, triterpenoids, and saponins. They are anticancer, anodyne, refrigerant, sedative, pectorial, styptic, stomachic and tonic.

\section{CONCLUSION}

The study has revealed the ethno medicinal and therapeutic uses of 6 medicinal plants of the study area for the treatment of various diseases such as Cough, asthma, leucorrhea, and so many other disorders of human health .The plants products are used by the local people in form of folk remedies for medicinal purpuses. So the such type study can provide a basic tool documentation of traditional knowledge about medicinal uses of plants and help in the in situ or ex situ conservation of medicinal floral diversity.

\section{REFERENCES}

[1] Ambasta, S. P 1 (986) The useful plants of India. C.SI.R. New Delhi.

[2] Chopra, R.N Nayar, S.L and Chopra I.C (1965). Glossary of Indian medicinal plants. C.S.R.I New Delhi.

[3] Katewa, S.S and Sharma, R (2001). Ethno medicinal observation from certain watershed areas of Rajasthan. Ethno botany 10: pp 46-49

[4] Sharma, L.K and Kumar A. (2006) ethno medicinal and photochemical studies on some selected medicinal plants of Rajasthan. Indian journal of Environmental sciences.1 (10), pp 51-53

[5] Singh V. and Pandey, R P (1998). Ethno botany of Rajasthan. Scientific publishers. Jodhpur

[6] M. M. Bhandari (1978) Scientific Publishers : Distributors, United Book Traders, 1978 - 471 pages 